\title{
DEVIANT BEHAVIOR: PSYCHOLOGICAL PREVENTION AND PSYCHOLOGICAL INTERVENTION
}

\author{
Akhmetzyanova, A.I \\ Kazan (Volga region) Federal University, Kazan, Russia
}

\begin{abstract}
The purpose of the study is to carry out a retrospective analysis of the basic concepts, theoretical approaches to the prevention and correction of deviant behavior that exists in modern psychology. The main method of the research is a retrospective analysis of the literature. This study shows the direction of social and psychological care for adolescents with deviant behavior which include prevention (warning, cautioning) and intervention (overcoming, correction, and rehabilitation). In conclusion, various social institutions regulate deviant behavior of an individual. Public exposure may have the character of legal sanctions, medical treatment, social support and psychological assistance. Due to the complex nature of behavioral disorders their prevention requires overcoming an organized system of social and psychological influences. Psychological prevention and intervention are seen as areas of rehabilitation, correctional and correctional-educational work with individuals who have behavioral problems, the main purpose of which is to overcome the disorders of mental development. Implementation of effective psychological prevention and correction of deviant behavior of a person occurs only when a person turns it into operation, when a person makes a personal choice, sets new goals. In order to overcome the deviant behavior, people should be able to make choices, to assess the consequences of the decisions to regulate emotional processes accompanying behavior, i.e. to organize their own livelihoods with generally accepted norms, which ultimately helps to reduce existing strains of personality as well as its active socialization.
\end{abstract}

Keywords: Deviant behavior, psychological prevention, psychological intervention.

\section{INTRODUCTION}

There are significant negative tendencies along with the positive ones in society such as changing the way people live, intensified social differentiation and conflict, increasing number of at-risk families, a growing number of adolescents and young people involved in criminal activity and drug use. The fact raising concerns is that the part of adolescents and young people, not only from at-risk families, enters the informal youth associations of an antisocial orientation. The difficult criminogenic situation encourages psychologists to seek effective ways and means of warning and overcoming deviant behavior of adolescents and youth $[1,3,4,5,7,11,12,9,10]$.

Psychological assistance has two leading directions. They are psychological prevention

Corresponding Author Email: Anna.Ahmetzyanova@kpfu.ru (psychoprophylaxis) and psychological intervention (overcoming, correction) [5, 11].

\section{Analysis of Methods and Forms of Psychological Prevention}

Increasing crime and the "punishment crisis" led scientists to refer to the ideas of crime prevention. Prevention (prophylaxis) of crime and other forms of deviance is understood as influence of society, institutions of social control, individuals on criminogenic factors which results in reduction and/or desirable change of deviance structure and nonexecution of potential deviant actions [ $2,4,7]$.

Three levels of prevention are distinguished in the modern world of deviance study:

- General social prevention (it is the impact on the environment, ecology, economic, social and political conditions of life of 
the population for their improvement and harmonization;

- Special prevention (i.e. providing security measures, the impact on the at-risk groups, the elimination of the circumstances that contribute to deviant manifestations;

- Individual prevention [2].

The directions of general social prevention are to improve living standards, reduce the gap between the richest and the poorest layers.

Measures of special prevention are various and include both installation of the security alarm system, on-door speakerphones, and the psychological, social assistance to at-risk groups, effective social policy.

Individual prevention involves work with concrete adolescents who are registered with the police, drug users, etc.

The concept of prevention is more democratic than repression in comparison with punishment.

Social control is one of the forms of preventive methods, which provides effort of the immediate social environment, aimed at prevention of deviant behavior, punishment of deviants, their behavior correction, motivation, values, etc. Social control is carried out by the legal authorities using coercive measures, various social institutions and organizations which are provided by organizational or economic sanctions for deviant behavior; or may be expressed in the form of public opinion and ostracism $[9,10]$.

Eight components forming the system of social control are defined and described in standard and psychological aspects [8] in Russian scientific literature:

- Individual actions which are shown during active interaction of an individual with the social environment.

- The reaction of the social environment to an individual's action depends on objectively existing social rating scale derived from the system of social values, interests of social group and society in general.

- The reference of action to a specific category (which is socially approved or blamed) is the result of the functioning of the social rating scale.

- The categorization of action depends on the nature of the public consciousness, including public self-assessment and evaluation by the social group of the situations in which it operates (social perception).

- The character and the content of the social actions, carrying out the function of positive or negative social sanctions directly depends on the state of public consciousness.

- The reaction of an individual to a social action depends on the individual rating scale derived from the system of values and motivation of an individual.

- The individual's self-categorization is a result of functioning of an individual rating scale (acceptance of a role, identification with a certain category of persons).

- The self-categorization of an individual depends on a self-assessment and assessment of the situation within which an individual acts (individual perception). The nature of an individual consciousness depends directly on the subsequent individual action which is a reaction to social action.

Parson J.L. [14] analyzed three instruments of social control. In his opinion, these are isolation (used for the purpose of an excommunication of a deviant from other people, it does not even provide rehabilitation attempt), separation (means limited contacts of a deviant with other people, while he or she is not completely isolated from society that allows a deviant to get liberty early, if they are ready to follow norms of society), rehabilitation (when deviants can prepare for a return to normal life and implementation of their roles in society). 
It is wrongfully to consider preventive actions only from the standpoint of social control. It is appropriate in that case when there are social deviations of penal, criminal character both in behavior of an individual and among its immediate social environment.

Thus, for example, to suspend process of criminogenic development of groups, it is necessary to pay more attention not to their destruction but reorganization that is change, restructure of their activity, the relations and communication [4].

Prevention of deviant behavior should be the correction or change of moral values. Behavioral deviations practically at any age are closely connected with a problem of family relationships. The importance of the age period will increase in creation of psycho-correctional measures because the specific of the problem often depends on the age characteristics of a client.

In this regard, S.A. Belicheva divided the negative influence which an individual gets from the immediate social environment into direct and indirect desocialization influence [2]:

Direct desocialization influence is an influence by the immediate environment that directly demonstrates examples of deviant behavior when there are destructive social norms and values forming deviant personality.

Indirect desocialization influence of the social environment is determined by social and psychological, psychological and pedagogical, social and pedagogical factors.

It is necessary not only to neutralize direct desocialization influence of the social environment, but also to create the bringing-up environment in school, family and other groups to prevent desocialization. It will allow them to become the preferred environment of communication and activity with the high reference importance in the opinion of adolescents and to perform the functions of the leading institutes of socialization.

Thus, early prevention should be considered not so much from the standpoint of social control as from the position of preventive desocialization process and management of socialization process of adolescents.
It is necessary to neutralize direct and indirect desocialization influence and to carry out corrective measures and socio-psychological rehabilitation.

\section{Analysis of Methods and Forms of Psychological Intervention}

Psychological assistance is understood as providing an individual with information about his mental state, the reasons and mechanisms of emergence of psychological phenomena or psychopathological symptoms and syndromes. It is an active meaningful psychological impact on an individual for the purpose of harmonization of his mental life, adaptation to the social environment, prevention of psychopathological symptomatology and rehabilitation of an individual for the formation of frustration tolerance, stress and neurosis resistance.

We can formulate strategic objectives of psychological assistance to the adolescent personality with deviant behavior:

- the formation of constructive motivation (positive values, orientation to implementation of social demands);

- $\quad$ self-regulation improvement;

- an increase of stress resistance and expansion of resources of an individual;

- the development of vitally important skills;

- an elimination or reduction of nonadaptive behavior;

- an expansion of social communications and positive social experience of the personality;

- an increase of social adaptation level.

The main forms of psychological work in case of deviant behavior are the consulting, psychotherapy, socio-psychological training and organization of the bringing-up environment. A relatively new form is special departments in psychiatric hospitals for delinquent individuals with mental disorders. In these departments, the special attention is paid to the issues of socio-psychological rehabilitation of the personality. It is necessary to recognize that the most appropriate methods of social influence for the delinquent behavior are community punishment and 
behavioral therapy in its various modifications $[3,5$, $8,9,10,11,12]$.

Psychological correction in the closed institutions is focused mainly on the destruction of certain directives, representations, values, motives, stereotypes of behavior and formation of the new one to achieve self-realization of the personality in the society. Correctional work is urged to solve the conflict for both sides "personality - society", "personality - social environment", "personality group", "personality - personality".

Thus, the leading purpose of psychological correction of deviant behavior can be defined as an achievement of positive behavioral changes [7].

Penitentiary psychotherapy (psychotherapy in the conditions of places of confinement) is an important though poorly developed form of intervention. Its specificity is defined as an extremely stressful situation for an individual, influence of asocially adjusted leaders and impossibility of the normal relations of therapeutic alliance. The conventional methods are inefficient in this case. In this regard, the specific methods adapted for the penitentiary environment [8] are used.

Psychotherapy in the closed institutions is focused on the solution of a number of tasks. First of all, it is necessary to establish the need of an individual for the psychological assistance. Further, it is important to define personal features by the techniques adapted for the penitentiary environment or specially developed scales (providing the accounting of the distorting influences of the environment).

An important task is creation of "psychotherapeutic oases", the groups or the relations protected from the effects of destructive actions. The following topical issues are the removal of psychic tension (primarily by the relaxation methods) and decrease in sensitivity to criminal, stressful influence [16]. Finally, there is a need for social training and the ability to solve problems of the convicted person in a given environment, and to get out of it. In some cases, psychological work is combined with spiritual psychotherapy. It should be emphasized that penitentiary psychotherapy faces serious and often inextricable difficulties. Therefore, the activity of priests in some cases is the only form of psychological and social impact on the identity of the person who is serving punishment.

Efficiency of psychological influence in the case of delinquent behavior depends on the efficiency of complex of organizational (e.g. organization of an order and humane atmosphere in the institution), economic, pedagogical, medical, and social (e.g. social rehabilitation after release) measures $[9,10]$.

Difficult for realization but the most effective method is the creating of upbringing environment [13]. The main purpose of this approach is the removal of a person from a habitual, provocative environment that in turn should change the way of life of a person and cause personality changes.

Such forms of organization of the environment include labor groups for adolescents with deviant behavior. Life in upbringing environment is subjected to a number of rules. The basic rules are independent life support, mutual aid, strict submission to the head and elected bodies, strict observance of discipline and norms of inner life, following traditions.

Moreover, it is necessary to take into consideration information about subjective attitude of an adolescent to himself, behavior, social environment.

According to $\mathrm{K}$. Rogers, subjective attitude is very important. He showed that honesty and realness of understanding deviants and their social environment are the most significant among the factors influencing the forecast of future behavior of minors-deviants (socio-psychological atmosphere in the family, the degree of influence of acquaintances, friends, physical development, heredity, etc.) [15].

Self-correction is effective in the case when adolescent with deviant behavior estimates himself and the social environment as realistic. Selfcorrection includes a number of links as the adoption of an individual of goal, accounting of activity conditions, operating, programming, evaluation of results and correction. The realization of these links of self-correction also assumes a certain relation to the actions, rational use of the individual opportunities which is connected with selfexamination. 
At the heart of self-correction of actions are various social mechanisms of demonstration and interaction of individual features [11]. One of the mechanisms is the use by a person of his favorable opportunities and strengths. Self-correction as the effect of interaction properties of various levels of personality is based on certain social conditions and requirements: general social norms, psychology and pedagogical influences, specific conditions and requirements of activity. Selfcorrection should be considered in unity with the correction and regulation in accordance with the objective conditions and requirements $[8,9,10]$. The rigid, excessive regulation and correction leave few opportunities for manifestation of self-control and self-correction for realization of individual opportunities.

\section{CONCLUSION}

Thus, the leading purpose of psychological correction of deviant behavior of adolescent's personality is to achieve positive behavioral changes. At the same time, a variety of correctional methods and techniques can not diminish the role of psychologist. At all the stages of collaboration behavior of an expert remains the leading source of the reinforcement of positive changes in behavior of an adolescent, and the identity of the psychologist is the main instrument of his professional activity.

\section{REFERENCES}

Ahmetzyanova, A.I. (2015). Anticipation and Prediction Interrelation Neuropsychological Mechanisms at Youthful Age. The Social Sciences, 10: 399401. doi:10.3923/sscience.2015.399.401

Belicheva, S.A. (1994). Preventivnaya pichologiya. Moskva: Sotsial'hoye zdorov'e Rossii.

Bryanta D., \& Forsythb, C.J. (2012). The complexity of deviant lifestyles. Deviant Behavior, 33, 525 - 549. doi:10.1080/01639625.2011.636694

Burke, J.D., Loeber, R., \& Lahey, B. B. (2007). Adolescent conduct disorder and interpersonal callousness as predictors of psychopathy in young adults. Journal of Clinical Child and Adolescent Psychology, 36, 334-346.

Cava M.J., Musitu G. \& Murgui S. (2007). Individual and social risk factors related to overt victimization in a sample of spanish adolescents. Psychological Reports, Ammons Scientific, Ltd, 101(1), 275-290

Corkina, D, Wiesnerb M., Reynab, R. S., Shuklac, K. (2015). The role of deviant lifestyles on violent victimization in multiple contexts. Deviant Behavior, 36, 405-428. doi: 10.1080/01639625.2014.935690

Dalbert, K., \& Filke, E. (2007). Belief in a Personal Just World, Justice Judgments, and Their Functions for Prisoners. Criminal Justice and Behavior, 34 (11), 15161527, DOI: $10.1177 / 0093854807306835$

Gilinsky, Ya.I. (2004). Deviantologiya: sotsiologiya prestupnosti, narkotizma, prostitutsii, samoubystv i drugikh otkloneny. Sankt-Peterburg: Yuridichesky tsentr - Press.

Kleyberg, Yu.A. (2001). Psikhologiya deviantnogo povedeniya. Moskva: Sfera, Yurayt-M.

Kleyberg, Yu.A. (2004). Sotsialnaya psikhologiya deviantnogo povedeniya. Moskva: Sfera.

Linfoot, K. Martin, A.J. \& Stephenson, J. (1999). Preventing Conduct Disorder: A study of parental behaviour management and support needs with children aged 3 to 5 years. International Journal of Disability, Development and Education, 46, 223-246. DOI: 10.1080/103491299100641

Mendelevitch, V.D. (2004). Psikhologiya deviantnogo povedeniya. Sankt-Peterburg: Rech.

Mendelevitch, V.D., \& Makaricheva, E.V. (2002). Antitsipatsionnaya sostoyatel'nost' v strukture lichnosti podrostkov $\mathrm{s}$ deviaciyami $\mathrm{v}$ povedenii. Detskaya psihiatriya, 1, $195-197$.

Minullina, A.F. (2014). Research of Anticipation Consistency in the Families of Drug Addicts. Middle-East Journal of Scientific Research, 8, 1099-1103. doi: 10.5829/idosi.mejsr.2014.19.8.21042

Parson J.L. Work, employment and unemployment in the Soviet Union. - Oxford, 1990.

Rodzhers, K.K. (1986). Nauka o lichnosti. Istoriya zarubezhnoy psikhologii. Moskva: Moskovsky gosudarstvenny universitet.

Zmanovskaya, Ye.V. (2007). Deviantologiya (psikhologiya otklonyayushchegosya povedeniya). Moskva: Rech. 